\title{
THE ECONOMICS OF UNEMPLOYMENT COMPENSATION
}

\section{EWAN CLAGUET}

Socral security and other general welfare measures have vitally affected the American economy for more than a decade. The mere listing of the more important of these measures is impressive: the emergency unemployment relief activities-federal, state and local-from 1931 on; the emergency cashing of World War I adjusted-service certificates in 1930 and 1931; the civil works (CIVA), work projects (WPA), and public works (PIVA) activities-federal, state and local; the expansion of public assistance, including general assistance on a state and local basis, as well as aid to the aged, dependent children and blind on a federal-state matching basis; and the social insurances, including federal old-age and survivors inșurance, federal-state unemployment compensation and railroad retirement and unemployment insurance. Many billions of dollars have been paid out under all these programs combined since 1929 , and many billions also have been collected in taxes to finance such programs. It is no exaggeration to say that the social and economic conditions in the United States in the 1930 s and 1940s would have been markedly different had these programs not been in operation.

Among all these various programs unemployment compensation has had perhaps the most far-reaching economic effects. This is not because unemployment compensation has been throughout the years the largest program in terms of expenditures (because it has not been), nor because it touches more people (because it does not), nor because it has been longer sustained (public assistance is much older). But unemployment compensation has other features which give it great weight as an economic force: it is both a taxing program and a benefit payment program; it is financed almost wholly by a payroll tax upon employers; it has a system of experience rating which brings about variations in employer taxes from state to state, industry to industry, and firm to firm; its activities fluctuate with business conditions, not only in contribution rates of employers but in benefit payments to the workers. No other program is so sharply and quickly affected by economic conditions, and in turn so directly affects the Nation's economic life.

The unemployment compensation program (including the federalstate system of unemployment compensation and railroad unemployment insurance) has been in operation since January 1936. ${ }^{1}$ From

$\dagger$ Director, Bureau of Employment Security, Social Security Board. The opinions expressed are those of the writer and do not necessarily represent the views of the Social Security Board.

1. In the State of Wisconsin an unemployment compensation law mas pacsed in 1932, collection of contributions began in July 1934, with benefits first payable in July 1936. The 
January 1, 1936, to June 30,1945 , the unemployment compensation system has collected a total of $\$ 9$ billions in taxes, has paid out $\$ 2.2$ billions in benefits, and had reserves as of June 30,1945, of approximately $\$ 7$ billions. In the year 1944, about 31 million workers were employed in an average week in industries covered by unemployment compensation laws (including railroad); about 47 million workers earned some wage credits during the year, of whom about 38 million workers earned enough to be eligible for benefits if they became unemployed. The purpose of this paper is to review very sketchily and summarily some of the major economic effects of this program.

\section{Economic Effects of the Taxing Program}

As stated above, unemployment compensation is both a taxing and a benefit payment program. In fact, the federal law is primarily a taxing statute. Furthermore, because of the provisions for building up reserves in advance of benefit payments, the program began operations as a taxing program and continued solely on that basis for some time; it was not until July 1939 that all states were actually paying unemployment benefits. Finally, the occurrence of the war, with consequent prosperity and full employment, has again focused attention almost wholly on the taxing aspects of the program. It can truly be said that the benefit payment potentialities of the program have not so far even been tested. For these reasons it seems appropriate to begin with an analysis of the economic effects of the taxing program, leaving to the end the somewhat more speculative analysis of benefit payments and their influence upon the economy.

The current methods of financing unemployment compensation are the product of several divergent influences or factors. Chief among these are the influences inherent in the nature of the federal-state system established under the Social Security Act of 1935. The excise tax imposed by that act was not a tax to raise revenue for the payment of benefits to unemployed workers but an incentive tax, which was designed to encourage state legislatures to adopt unemployment compensation laws and impose taxes to meet the costs of the benefits. The character of the tax, however, was such that it set the pattern of financing adopted by the states when they passed their unemployment compensation laws.

The federal tax was and continues to be a 3 percent tax on payrolls. ${ }^{2}$

Railroad Insurance Act was passed in 1938 when the railroad industry was removed from coverage of the state unemployment compensation acts and a special unemployment insurance system created for that one industry.

2. The act provided for a 1 percent tax in 1936, a 2 percent tax in 1937, and a 3 percent tax for succeeding years. The railroad tax act also provided for a 3 percent payroll tax on railroads beginning in July 1939 , and continuing to the present time. This tax differs somewhat from the social security tax in that it is collected by the Railroad Retirement 
The device used to encourage states to pass unemployment compensation laws was the credit allowed the individual taxpayer if he paid taxes under such a state law. The maximum credit allowable was 90 percent of the 3 percent, or 2.7 percent of the taxable payroll. This tax offset provision was effective immediately. Another provision, which was not to take effect until benefit payments were well under way, permitted the allowance of additional credit if an employer had been assessed less than the 2.7 percent under experience-rating provisions which met the requirements of the federal act.

The choice of an employer tax on payrolls and the provision for experience rating largely grew out of concepts taken over from workmen's compensation. ${ }^{3}$ At the time the federal act and the state laws were enacted these concepts were generally accepted as applicable to unemployment compensation. Under those laws employers carry the full cost of accident insurance for their workers. The employer's payroll is used to determine the extent of exposure to such accidents, and contributions are collected on the payroll at rates which vary vith the degree of the accident risk among industries and employers. These ideas were carried over into state unemployment compensation laws in the form of an employer payroll tax with provision for subsequent rate variations. This pattern was the direct result of the federal act and the theories which had gone into the drafting of the act.

The system did not in itself provide any place for employee contributions or government contributions in the financing of benefits. In the light of the major federal objective, there seemed no point in assessing employee contributions through the federal government. The inequity of taxing employees in a state which might not even have an unemployment compensation law was readily apparent. Moreover, there is an essential incompatibility between the theory which supports variable rates for employers and the theory which justifies a contributory unemployment insurance system supported jointly by worlkers and employers. On the other hand, the system did leare the way open for employee contributions, and for government contributions also, if the states wished to have them. Ten states at one time or another assessed employee contributions, but in only four " do these still exist. If a lower rate of employer contribution had been established under the federal act, or if unemployment had been more severe in the years since the act was passed, the employer contribution alone might not have proved adequate. In those circumstances it is possible that either

Board rather than the United States Treasury, and it is used to pay unemployment banefits specified in the railroad unemployment insurance act. The railroad system differs essentially from the federal-state system in that it provides a national system of taxes and bonefits for a specific industry. Also, it is a uniform tax with no provision for experience rating.

3. See Anold, Esperience Ratistg, page 218 infra, at 220.

4. Alabama, California, New Jersey, and Rhode Island. 
employee contributions or government contributions, or both, would have been incorporated in the present system of unemployment compensation. The District of Columbia law, as initially passed by the Congress, did provide for government contributions during the first years of the program. ${ }^{5}$

Neither employee nor government contributions have become an essential feature of the program, however. The character of the federal act is not alone responsible for this; more fundamental is the fact that employer contributions have been more than adequate in all states to finance the benefits that have been payable during the past eight years.

The first important objective of this federal tax offset provision was to stimulate passage of state unemployment compensation laws with state taxing provisions and state benefit schedules. ${ }^{6}$ There was in the beginning considerable doubt about the constitutionality of federal unemployment insurance legislation. ${ }^{7}$ It was feared by the Committee on Economic Security that if the unemployment compensation program established by the Act were to be made wholly dependent upon federal law, the whole program would be eliminated by unfavorable court action. On the other hand, if federal action consisted simply of taxation which would stimulate the passage of state laws, the program as a whole would become firmly embedded in state legislation and might survive even though the federal law should be declared invalid by the Supreme Court. Some opinion was expressed at that time to the effect that the tax offset program would not result in the widespread passage of state laws, and that therefore this first objective would not be attained. In actual fact, this fear soon proved to be unfounded. Long before the Supreme Court had passed judgment on the legislation, most states had passed laws, and by May 1937, when the Court decision was rendered, 45 states had laws on the statute books. The remaining three states came into the program prior to July 1,1937 . The first objective was therefore attained completely within a period of two and one-half years.

5. Section 5 of the 1935 Jaw, 49 STAT. 949 (1935), provided: "(a) The District of Columbia shall pay contributions, in addition to its contributions as an employer, in the following amounts: For the calendar year 1936, $\$ 100,000$; for the calendar year 1937, $\$ 125$,000 ; and for the calendar year 1938, $\$ 175,000$. (b) The contributions required by this section for each calendar year shall be paid by the District of Columbia to the Board and shall, immediately upon receipt by the Board, be paid into the District Unemployment Fund." The section was repealed, effective July 1, 1943. See 57 STAT. 100 (1943).

6. For a more complete discussion see Cosmitrex on Economic SEcurity, Soctal Security in Asrerica (Social Security Board, 1937); Levveretr S. Lyon, Vrctor AuraMson, et al., Government and Economic Life: Developarent and CuRrent Issues of American Public Policy (Brookings Institution, 1940) 2 vols. See also Untemployment Compensation in SOCIAL WORK YeARBooK: 1941 at 576-7, and SOCInL WORK Yeargook: 1943 at 531-9.

7. The unemployment compensation features of the Social Security Act were declared constitutional by a 5-4 vote of the Supreme Court in Steward Machine Co. v. Davis, 301 U. S. 548 (May 24, 1937). 
The second, longer-range objective of the federal tax was the elimination, or at least the restriction, of interstate competition with respect to unemployment compensation legislation. The federal tax was uniform for all employers and all industries affected by it. During the initial years at least, employers in like circumstances anywhere in the country were subject to the same tax rate, and the offset provision insured that employers in a state with an unemployment compensation lav need not pay higher rates than employers in a neighboring state without such a law. All employers covered under the Act paid the same rates; all industries were on an equal footing. ${ }^{8}$ It is vitally important to emphasize that this elimination of inter-state competition was originally the cornerstone of the present federal-state system of unemployment compensation. It was this which made possible the rapid spread of the program throughout the states and which insured the maintenance and expansion of the program during the early years of its existence.

Apart from the general taxing provisions of the Act, there was one other provision which played a minor part in lessening competition among the States. Under the Act, the Federal gorernment pays all the cost of administering State unemployment compensation laws. Because of this responsibility, the tax offset was limited to 90 percent of the 3 percent tax. The remaining 10 percent portion of the federal tax is collected by the federal government as general revenue. Congress in turn appropriates the necessary funds which are allotted to the states as administrative grants. This 0.3 percent tax is uniform for all employers in states. Therefore, any differences in administrative costs among the states do not reflect themselves in varying tax burdens upon employers in those states.

\section{VARIATIONS IN RATES BETIVEeN EAIPLOYERS}

During the first five years of operation (1936-1910) the unemployment compensation program developed in accordance with its original objectives; the next five years, however, were characterized by the rapid spread of experience rating until, as of June 30,1945 , all but six states had experience-rating laws on the statute books, and all but nine had schedules of reduced rates in actual operation. The effect of experi-

8. A question has been raised as to whether the payroll tax is in fact truly uniform for all industries and all employers inasmuch as it falls more heavily upon those industrics and firms employing relatively large amounts of labor; in such industries payroll costs constitute a high proportion of operating costs, thus causing employers in those industries to pay more unemployment compensation taxes than those employers having low labor costs. It has been further contended that in some industries employers could readily pass on the tax to consumers as part of the cost of production, while in others this is difficult or impossible. Nevertheless, making allowance for whatever imperfections there may be in a payroll tax, the principle is clear: the risk of unemployment is directly ascociated vith the number of workers employed; the tax falls uniformly upon the wages paid to those worlsers. The first incidence of the tax is, therefore, reasonable. 
ence rating has been to change the original idea of tax uniformity into a highly complex system of tax variation. The experience rates in unemployment compensation are determined upon an individual employer basis in each state; the rate schedules usually contain numerous classes of rates; and rates are redetermined every year. As a result, the outstanding fact about unemployment compensation taxes is that they fluctuate from year to year, and may be widely different for firms in the same industry in the same state, or even for the same firm operating in the same industry in different states. It is said that one of the vitally important characteristics of a good tax is certainty; by this criterion alone this is not a good tax for its outstanding characteristic is its uncertainty.

It is curious that the essential inconsistency between this system of experience rating and certain basis objectives of the unemployment compensation program was not at first generally recognized. During the House Ways and Means Committee hearings in 1935, the Hon. Jere Cooper called attention to the possibility that the variations in employer tax rates under such plans might lead to general reductions in rates which would leave some employers in some states more favorably situated than others, but the warning was not heeded. ${ }^{\circ}$ There were several reasons for this. First, the unemployment experience of the country during the 1920 s and early 1930 s made it seem likely that the 3 percent payroll tax would, if anything, be insufficient for an adequate unemployment compensation program. It was thought that the states might be concerned more with devising additional sources of revente, such as employee contributions, than with cutting employer rates. Second, the experience rating was designed to work both ways: to lower the rates of those employers who had a favorable experience with unemployment, and to raise the rates for those whose experience was unfavorable. Thus in Wisconsin the state tax ranges from a minimum of 0.0 percent for employers with large reserves to 4.0 percent for those with impaired or non-existent reserves. ${ }^{10}$ While it was not likely that the higher tax rates from the penalty contribution rates would always exactly balance the lowered rates from the reduced rates, it was at least likely that such a spread in rates would prove to be a stabilizing factor in maintaining an average contribution rate for the state as a whole not too far above or below 2.7 percent.

Several factors combined to bring about a fundamental change in thinking and in action. By far the most important of these was the great business revival, culminating in the national defense program and eventually in the war itself, which reduced benefit payments to in-

9. Hearings before Committee on Ways and Means on H. R. 4120, 74 Cong., 1st Sess. (1935) 145-7.

10. For "war-risk" provisions of the Wisconsin law see page 66 infra. 
significant levels. Moreover, the enlarged payrolls of the prosperity period brought in greatly increased revenue.

For the unemployment compensation program as a whole, and even more spectacularly for individual states, current income of the fund was increased, current outgo was sharply reduced, and greater reserves were piled up; by 1944 for the country as a whole the interest earned on the reserves was far in excess of all benefit payments for the year. This favorable financial development had two immediate consequences: first, many states which had not previously done so adopted plans for experience rating; and, second, states which had already adopted experience rating modified their previous plans or changed their schedules of rates. Experience rating as a system of taxation was the sole beneficiary of this situation because there was no other method of obtaining tax reduction. A uniform or flat rate reduction from the standard 2.7 percent tax rate on individual employers could not be adopted because the federal act requires that rate reductions be based on individual employer experience. Congressional action would have been necessary to make flat reduction possible. Hence, a number of state governments, which might have preferred to effect a tax readjustment through a uniform reduction in all employer rates, were unable to do so. The logical conclusion which must follow from the present system is that all states able to finance a reasonably adequate program on less than 2.7 percent will eventually adopt some form of experience rating.

The second consequence was that states amended their experiencerating provisions by eliminating penalty rates and making the standard rate of 2.7 percent the maximum rate. Not only did this dampen the opposition to experience rating on the part of employers who otherwise would have paid higher rates, but it also had the effect of lowering the average yield in the state well below 2.7 percent. States without previous experience-rating plans refused to consider the penalty rates as a part of such plans. As of June 30,1945 , of 45 state laws embodying experience-rating systems ${ }^{11} 17$ made provision for penalty rates. ${ }^{12}$

Therefore, experience rating, which started out as a device for spreading employer contribution rates both above and below the normal rate of 2.7 percent, is gradually becoming simply a device for reducing contribution rates below the normal rate. Of course, there is still a spreading of the rates, but the range is narrower, and the concept of a penalty rate is dying out. The range is, in fact, too narrow to reflect adequately the differences in the experience of individual employers with unemployment.

The consequences of these developments in experience rating can be

11. Including Nevada and New York, effective July 1, 1945.

12. Including Nevada, effective July 1, 1945. 
summarized very simply by an illustration from a group of neighboring Middle Atlantic states:

Connecticut ${ }^{13}$

New York (no experience rating) ${ }^{14}$

New Jersey (not including $1.0 \mathrm{em}$ ployee contribution)

Pennsylvania

Delaware

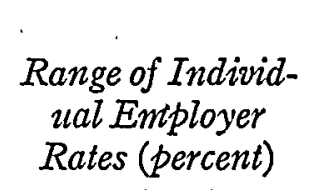

$1.5-2.7$

2.7

$0.9-3.6$

$1.0-2.7$

$0.5-3.0$
Average Contribution Rate for State as a Whole, I944 (percent)

2.1

2.7

1.8

1.5

0.8

Here are five states in reasonably close business competition with each other, yet the percentage over-all yield in New York was more than three times the percentage yield in Delaware, while some New York employers may be paying five or six times the rates of their competitors in'Delaware. ${ }^{15}$

As we look back over the history of unemployment compensation during the ten years since the passage of the Social Security Act, we can readily see that objectives have become distorted and unforeseen results have occurred. Uniformity of tax rates has given way to variations and fluctuations. Variations in rates among employers (experience rating) have become hopelessly entangled with tax reductions arising from general economic conditions. It is interesting to speculate on the situation in which unemployment compensation would find itself today if there had been no provision for experience rating. In that event the issue of tax reduction would have had to be faced clearly at the federal level, as it has been faced in federal OASI. Each year, during recent years at least, the amount of the uniform federal unemployment compensation tax rate would have been an issue in Congress with the result that it would have been debated on its own merits. In actual fact, however, tax reduction has been forced into the mold of experience rating by the additional credit provisions in the federal act. The extent

13. Connecticut and Pennsylvania vary experience-rating schedules with the condition of the fund.

14. In April 1945 New York adopted an experience-rating system under which rates are based on the employer's experience with yearly and quarterly payroll declines, modified by the number of years (up to eight) the employer has been liable for contributions under the state law.

15. A note of caution is in order here. Of course, there are many firms and industrics which are in a non-competitive position from state to state, e.g., retail stores and local public utilities. These are scarcely affected by the differences in payroll tax rates. Furthermore, these differences in taxes may be small in comparison to variations in other costs. Firms operating on narrow margins and which sell their products in interstate commerce are the ones which will feel the greatest effect of these rate differentials. 
to which this anomaly can exist is dramatized by the rates in the District of Columbia for 1945 . While new firms must pay the 2.7 percent standard rate, the experience-rated firms (comprising 66 percent of all active accounts in the District) have rates varying from 0.1 percent to 2.7 percent with 89 percent of the subject payroll taxed at the 0.1 percent rate.

Conversely, experience rating itself is becoming distorted by being used as a vehicle for tax reduction. In all truth, the friends of experience rating can say that that system has not yet had a fair trial. The fundamental purpose of experience rating was to stimulate stability of employment by awarding lowered rates to employers who succeeded in achieving that objective. Employer rates have been drastically reduced in many states throughout the country in the last three years, yet the fact is that employers generally have had very little control over their respective businesses during the past five years; nor do experience rates reflect to any appreciable degree the efforts of individual employers to stabilize their employment. Yet experience rating has, in the eyes of many employers, obtained the full credit for the reductions in rates which have so far occurred, and it is likely that the system will suffer the discredit of being held responsible for the rising rates in the postwar period, during which, also, employers generally will be at the mercy of influences beyond their control.

While experience rating has been the means of getting rate variations, these variations do not accurately reflect the true purpose of experience rating. They partly represent what might be called almost purely arbitrary influences upon the employers' costs of production. Ignoring the present wartime situation and looking to the longer future, we can say that, under the present federal-state unemployment compensation system, the rates which an employer must pay will be determined by three factors: (1) the relative amount of unemployment in each state as compared to other states; (2) the comparative liberality of the various state laws, and the policies which the state agencies follow in the administration of those laws; and (3) the type of experience rating adopted, including the methods used in measuring the experience of employers with unemployment, and the methods of assigning rates on the basis of that experience. These factors, while they can be distinguished from one another, do not operate independently of each other; there is considerable interaction among them, especially between the second and third.

Unquestionably, all three of these factors making for rate variation can operate in strictly economic fashion on an employer's business. In a state where industries are more unstable and unemployment is likely to be heavy, unemployment compensation will require higher rates of payroll taxes on employers than in a neighboring state where indus- 
tries are generally more stable. For example, Michigan and Pennsylvania would, on past experience at least, require higher tax rates than Ohio and Wisconsin. Likewise, under identical circumstances it presumably costs more to finance higher benefits for longer periods of time; therefore a state which has a low schedule of benefits and short duration may require lower taxes than one which has a more liberal law. Finally, if experience rating is to achieve the purpose for which it was designed, it should produce lower rates for the stabilized employer having few layoffs and force higher rates on the unstable employer with a large labor turnover. Due to the wartime conditions which have existed since 1940, the possibilities of experience rating in this connection have never yet been really tested and cannot be until sometime in the longer future when more "normal" conditions may exist. ${ }^{16}$

However, this is only half the story. The differences in the legal provisions of state experience-rating laws frequently have no economic basis and are often quite erratic in their economic consequences. One outstanding example is the variety of methods used to identify the employer who should be held responsible for a worker's unemployment. This has been a thorny problem and illustrates one of the difficulties in the attempt to adapt the merit-rating system of workmen's compensation to the purposes of unemployment insurance. Under workmen's compensation laws the employer to whom a worker is attached is clearly identified since the injury to be compensated occurs during the period of employment; that is, the employer-employee relationship exists at the moment of the accident. In unemployment compensation, however, the contingency does not occur simultaneously with the employment but only after the employer-employee relationship has been broken off. Except in cases of partial or very temporary unemployment, the unemployment of the individual worker occurs after he has severed his connection with all employers. As a result there is no one method of determining which of a worker's prior employers should be held responsible for his unemployment. A wide variety of methods, with numerous variations, are used in making "charges" against an employer's experience-rating record. ${ }^{17}$ For the purposes of this article the significant point is that these different methods bring about very different results in terms of the payroll tax rate.

It is usually argued that while these charging methods may cause variations in tax rates that are highly uneven and erratic in detail, they balance out fairly well in the long run. At one time the "last" employer may find himself saddled with a heavy burden of charges because a particular ex-employee drew benefits at a certain time; in another case

16. See Arnold, Experience Rating, page 218 infra, at 237.

17. Seeid. at 234-5. 
he will be more fortunate and find that some other employer has borne the whole charge. In some measure this argument is valid; among millions of employees and hundreds of thousands of employers there is some "evening up" as among these different systems, so that they are not as far apart in their effects as might appear in individual cases. The main weakness of the argument is that it proves too much. There are very decided limits to this "evening up." For example, a small employer with a few employees lacks the advantage of a large employer with thousands of employees. For this small employer, a few unfortunate charges may keep up his rate for years. Again, certain industries may find themselves heavily burdened with charges under one system which they would scarcely feel at all under another system. This is probably not yet realized by employers generally, but the fact is that the charging process in vogue in a particular state may have fully as much to do with an employer's rate as the actual extent of unemployment among his ex-employees.

Finally, interstate concerns will find that the personnel policies which will avoid benefit charges in one State may be exactly opposite to the policies which will be necessary in the neighboring State in order to achieve the same result. In one state a short general layoff followed by reemployment of the men may be the best way to avoid heavy benefit charges; in another state this may be the worst thing that could be done. In some states credit is given for rehiring former employees, so that the employer may gain lower rates by looking up his ex-employees who are drawing benefits and rehiring them in preference to other workers; in other states such a policy has no effect whatever on his rate.

Thus the variations in employer tax rates for unemployment compensation are due in part to the operation of several economic factors to which a business concern presumably could adapt in the long run. However, these variations are multiplied by the operation of noneconomic factors of an erratic character, factors to which it would be difficult for the average concern to adapt. The conclusion must be that in the light of the economic conditions of the past five years, and in terms of the complexities of experience-rating as it now exists, the average employer's tax rate in unemployment compensation is now largely the result of fortuitous factors which affect his business in ways which he can neither understand nor overcome.

In the postwar period a determined effort is to be made to stimulate small businesses and new businesses. This is a cardinal policy of the federal government. It is especially significant in the case of exservicemen who will be enabled to borrow capital to finance new enterprises. These new concerns will be required to pay for a period of 3 years the standard rate of 2.7 percent while many of their older 
competitors, enjoying the low rates of wartime prosperity, may be paying rates of 1.0 percent, 0.5 percent, or even less. This may under certain conditions constitute a differential in taxes sufficiently great to affect to some extent the chances of the new firms for survival. This adverse effect could be eliminated if a revised uniform tax rate were assessed on all employers (which would mean the abolition of experience rating), or if the standard rate were lowered, with effective experience rates established above and below the standard. A lower tax rate for new businesses is one of the urgent reasons for reconsidering the financing of unemployment compensation. Needless to say, the old-age and survivors insurance tax rate is not subject to this criticism.

\section{Fluctuations in Rates over Periods of Time.}

The variations in rates discussed so far are those which are current among states and among employers. This is in a sense a static analysis of rate variation. If we now introduce the element of time, we find that there exists another type of variation, possibly even more important from the point of view of the economy as a whole. This is the general variation in rates which occurs from year to year or from period to period. Regardless of whether or not we can establish the doctrine of a periodic business cycle, we do know that there are fluctuations in business conditions, so that at times business is good and unemployment is low, while at other times business is bad and unemployment is high. For example, in 1940 the entire system paid out $\$ 518.7$ millions in benefits, while in 1944 it paid out only $\$ 62.4$ millions. In some postwar year it could pay out several billions of dollars. In view of the fact that unemployment compensation is designed to offset the effects of loss of jobs, it is natural that the benefit payments will fluctuate widely from time to time.

One problem of financing involves the question of how we should arrange the contributions of the employers to meet benefit costs. The theory which was adopted in this country in the passage of the Social Security Act was that reserves for unemployment compensation should be set aside in advance. The original act provided, in effect, that reserves on hand at the beginning of benefit payments should be at least equal to one full year's contributions at the 2.7 percent rate. In addition, it was expected that additional reserves would be built up in subsequent years so that ample funds would be set aside to meet any contingency. No provision was made for borrowing. This doctrine of reserves has been carried so far that twelve states have provided for reductions in benefits whenever reserves fall below a certain point. Most states make experience rate reduction contingent upon the condition of the reserve.

In actual historical fact, no state suffered insolvency in the first year 
of benefit payments, and in only a few states paying benefits in 1938 was it necessary to draw at all on the reserves which had been established before benefit payments began. In the rast majority of states the contribution system yielded more current income than was necessary to pay the benefits provided by law. Historically, the unemployment compensation system in this country has turned out to be overfinanced. In all but a few states, reserves have been accumulated ${ }^{13}$ which are ample to pay off for some years to come all the benefits payable under present laws, and even the much higher benefits which might be desirable. This is one factor which hastened the adoption of experience rating throughout the country.

If the federal act had prorided an offset at a uniform fixed rate for all employers, there would have been an automatic adjustment between the amount of unemployment tax collections and the amount of benefits payable prospectively over a period of years. With a fixed rate applied to a tax base which automatically fluctuates with business conditions, i.e., the payroll, the unemployment funds would have benefited from increased revenue in periods of business activity and employers would have paid less in taxes during periods of recession, with the result that a more consistent relationship would have been established between income and potential liability. Then payrolls increase the number of individuals with benefit rights increases, and a sound system of finance should provide for increase in revenue.

When both rates and payroll fluctuate, as under the present sy'stem, the financial result is unpredictable. The effect of rate reductions on the income may be lessened or aggravated by changes in payroll. The effect upon income is the same if the rate is reduced from 2 to 1 percent as it would be if the taxable payroll were cut in half. Obviously, if both the rate and the taxable payroll are reduced by 50 percent at the same time, the income is lowered to one-fourth of its prior level. On the other hand, if the rate is reduced and the payroll increases sufficiently, the former level of income can be maintained or increased. In any case the result cannot be accurately forecast.

The picture is further complicated by the form and variety of indexes which have been adopted by the states for the purpose of establishing the relative experience of employers with unemployment, and the variety of the methods used in assigning rates on the basis of the index. Under the reserve-ratio system, the benefits which are paid to his workers are subtracted from the contributions paid by an employer and the balance is compared with his payroll to establish his reserve

18. Many states had accumulated more than the equivalent of 2.7 pereent of payroll before they began paying benefits; for example, Illinois and Montana had accumulated the equivalent of 6.75 percent of payroll. 
ratio. ${ }^{19}$ If his payroll increases more rapidly than the reserve, his reserve will fall and his tax rate will increase. Under other plans, the opposite is true. For example, under the benefit-ratio plan benefits paid to the employer's workers are compared directly with his payroll. If the payroll rises, the ratio is lowered and the employer receives a lower rate. Under the reserve-ratio system the pull of an increasing payroll is in the direction of higher rates; under the benefit-ratio, in the direction of lower rates.

Another formula bases the long-run financing of the program upon the "replenishment" theory of contributions. Under this system the rates of individual employers are designed to bring in the amount necessary to replenish the fund for any outgo due to benefit payments. In its extreme form, this method replenishes each year the amount expended in the preceding year. The amount is distributed among employers in accordance with their relative experience with separated workers who have drawn benefits. If the amount to be raised is large, each employer will carry a heavier tax burden. At present, with prosperity at a high level and benefit payments almost negligible, contribution rates of employers are at a minimum. With the first shock of postwar unemployment, benefit payments will multiply and the amount to be raised by the employers will increase. If the tax on the covered payrolls is to yield the needed amount, rates will have to be substantially increased since declining payrolls will throw the burden of the increase on the rate.

While the formulas in some states, notably those using the reserveratio, greatly modify this effect, an almost inescapable result of basing future rates on the experience of employers with unemployment in the recent past is that the rate will be low during and immediately following periods of sustained prosperity and high during periods of continued depression. When business conditions show abrupt changes, the situation may differ. Rates in the first year or two of a depression may be low if the depression follows a period of extensive employment. Clearly, those state laws which base rates on experience over a long period are less erratic in this respect. However, even in these states, the experience of the war years with their abnormal employment and negligible benefit payments so far outweighs the experience of the earlier years in which the program was in operation that the employers generally are paying contributions at a relatively low rate. State administrators have become aware of this development, and in some instances have persuaded state legislatures to take action to counteract it. In Wisconsin, for example, a general levy of 0.5 percent was assessed on all employers in 1944 and 1945 for the purpose of creating an

19. For a more extended discussion of these systems see Arnold, Experience Raling, page 218 infra, at $229-230$. 
extra postwar reserve. ${ }^{20}$ In the same state special increased rates were assessed on war-expanded industries whose risks of shutdown in the postwar period were thought to be greater than average. Eleven ${ }^{21}$ other states have adopted similar "war-risk" provisions.

A temporary step to meet postwar emergencies has been taken by the federal government. Under the George Act, passed in 1914, provision was made for the maintenance, during the period July 1, 1945-October 1, 1947, of a federal unemployment account in the United States Treasury. During the years July 1, 1945-July 1, 1947, states are entitled to borrow from the account when their own unemployment reserves are less than the equivalent of a year's contributions.2: This is not a reinsurance fund, but an advance, without interest. The amount of the advance is limited to cover the cost of those benefits in any calendar quarter which are in excess of 2.7 percent of the state's taxable payroll, and must be repaid when the state's account has again risen to the required level.

There is much to be said for introducing the concept of borrowing in the financing of the unemployment compensation program. If a state has the possibility of borrowing, there is less urgency about the creation of a large reserve in advance; at least, there is no need for the maintenance of an excessive reserve. Reduction of benefits to unemployed workers in the midst of depression, simply because the reserve has been temporarily exhausted, is a most unwise social policy; it should be adopted only in dire emergency and as a last resort. It should be possible to finance unemployment compensation on a reasonable

20. A 1945 amendment to the Wisconsin act provides that, effective in $1947,0.5$ percent will be added to an employer's tax whenever his payroll has increased 20 percent or more over the payroll in the prior year.

21. Alabama, Florida, Georgia, Illinois, Iowa, Iansas, Maryland, Minnesota, Missouri, Ohio, and Oklahoma. The provisions in Georgia and Kansas were adopted during the 1945 legislative sessions.

22. Section 1201 of the Act, 58 Stat. 790 (1944), 50 U.S.C. app. $§ 1607$ (Supp. 19:4), provides:

"(a) In the event that the balance in a State's account in the Unemployment Trust Fund on June 30,1945, or on the last day in any ensuing calendar quarter which ends prior to July 1,1947 , does not exceed a sum equal to the total contributions deposited in the Unemployment Trust Fund under the unemployment compensation law of the State during that one of the two calendar years next preceding such day in which such deposits were higher . . . .

"(c) Any amount transferred to the account of any State under this Eection shall be treated as an advance, vithout interest, to the unemployment fund of such State and shall be repaid to the Federal unemployment account from the unemployment fund of that State to the extent that the balance in the State's account in the Unemployment Trust Fund at the end of any calendar quarter, exceeds a sum equal to the total contributions deposited in the Unemployment Trust Fund under the unemployment compensation law of the State during that one of the two calendar years next preceding such day in which such deposits were higher. . . .". 
basis throughout the whole business cycle without the danger that the entire program of benefits will be upset because at some given period of time there is a temporary shortage of funds. Moreover, a system of combining reserves and loans as a means of financing the unemployment compensation program has a further advantage over the straight reserve plan. Since it is extremely difficult to tell in advance what the compensation demands of the future will be, it is well to have a general contingent fund from which states can borrow.

So far as tax policy is concerned, the developments of the last five years are unfortunate in one respect at least-attention has been centered upon individual employer rates instead of upon the over-all statewide yield. Had flat-rate reductions been possible, some states in recent years might have adopted uniform rates of less than 2.7 percent rather than experience rating. Had they done so, more attention might have been paid to the basic problem of the financing of the states' unemployment benefits as a whole, and particularly to the financing over longer periods of time. As it is, the concentration upon rates geared to the experience of the individual employer has diverted the attention of employers from the central financing problem. The results will probably not become apparent to employers generally until the unemployment of the postwar period focuses sharp attention. upon benefit costs.

\section{Economic Effects of the Benefit Progran}

Thus far attention has been centered upon the economic effects of the tax rates in unemployment compensation. These are important; they affect the cost of production of individual businesses and they operate with differing effects upon different industries and upon different States. The other side of the economic picture is the flow of benefit payments to unemployed workers. How does this affect the economy?

\section{Benefit Payments and Purchasing Power.}

Supporters of the "spending" theory of prosperity would defend the payment of unemployment benefits but would deplore their inadequacy. By no stretch of the imagination can unemployment benefits be regarded as a substitute for full-time wages. Weekly benefit payments at best run only about 50 to 60 percent of wages while, for the higher wage workers, weekly benefits may be as low as a third or a quarter of wages. An extremely rough calculation made in the Bureau of Employment Security indicates that for the year 1944 the average benefits paid would have been about one-third of average wages in the states.

Moreover, the duration of unemployment compensation is limited. In some states workers can draw benefits for possibly 20-26 weeks, but 
in the majority for less than 20 weeks. When a worker exhausts his unemployment rights, he can no longer draw from the fund. Coverage is limited, so much so that approximately one-third of the persons gainfully employed in the country during a year have no rights at all, while many additional workers who are eligible for benefits have only very limited rights. Summing up all these factors, it has been shown that in a moderately serious postwar reconversion year, when the decline from present levels in the wages and salaries of American workers might amount to $\$ 20-25$ billions, the unemployment compensation system might pay out something approaching \$2-3 billions, only 10 percent. It would be difficult "to spend our way into prosperity" through unemployment compensation.

Furthermore, it is not the gross benefit payments which affect purchasing power, but the net payments over and above taxes currently collected. Even while large sums are being paid out in benefits during a business depression, considerable amounts are flowing in from the payroll tax. In 1944, total taxable payrolls for unemployment compensation amounted to more than $\$ 60$ billions, which yielded $\$ 1.15$ billions in taxes with a Nationwide average effective rate of 1.9 percent. If, in some reconversion period, such payrolls fell to $\$ 10$ billions, the standard rate of 2.7 percent would yield nearly $\$ 1.1$ billions in taxes.

This does not mean that unemployment compensation benefit payments have no economic effect. Within their limits they do serve as an element of purchasing power which practically all economists would agree is both important and timely. It is timely because unemployment compensation payments are made early in the downturn, immediately after unemployment makes its appearance. They enable workers and their families to preserve existing assets, such as homes, furniture, and automobiles, thus aroiding the forced liquidation of assets which aggravates the downturn in business. They encourage more confident spending of other resources, thus helping to avoid a "freezing" of purchasing power on the part of millions of workers when they are faced with unemployment. Payments are made weekly (in one state, bi-weekly) very much like wages, so that there is not a sudden lump-sum amount which may be spent erratically by the family, but instead a steady assured (though low) income for a period of four to six months. This means that these funds are ordinarily spent for the basic necessities of life and furnish purchasing power for the products of our basic industries, such as agriculture, food, and clothing. Benefits are designed to cover no more than the period of unemployment; when the unemployment is over and the worker has a job again, the payments cease. Finally, these benefit rights can be known to the worker far in advance-he can know while he is working what his rights will be in the event of unemployment. Therefore, they add to the security 
of employed workers and help maintain their spending habits at a time when business may be heading down hill. In summary, therefore, it may be said that these benefit payments have economic effects far greater and more supporting to the economy than their absolute amounts would indicate.

\section{Benefit Payments and the Labor Market.}

It has occasionally been argued that the benefits payable in the form of unemployment compensation operate as a drag upon the labor market, encouraging workers to resist changes in occupations and wage rates and hindering reemployment. These payments have occasionally been labeled as pure economic waste, maintaining workers in idleness when they would otherwise be earning wages at work. Is there any evidence that this is the case?

On a broad, general basis the answer seems clearly to be, no. Such views have usually arisen out of an ignorance of unemployment compensation and how it works. In the first place, the unemployed worker cannot obtain benefits for unemployment that is due to his having left work by his own voluntary action (voluntary quit) or to a discharge for misconduct, or if he is engaged in a labor dispute. In no case can he obtain benefits until he registers at a public employment office, to which he must return each week to put in his claim for benefits. Furthermore, he can be disqualified and deprived of benefits if he refuses any suitable work which may be offered to him through the employment office. Workers, therefore, cannot voluntarily retire to a state of idleness and draw benefits; they cannot maintain a state of idleness and continue to draw benefits if jobs are available. There may be administrative failures here and there throughout a vast organization stretching across the country, but these are the exception and not the rule. Under the administration of unemployment compensation, workers drawing benefits are generally doing so because (a) they have been laid off by their employers and (b) no other jobs are available for them.

In addition, the administration of unemployment compensation serves a useful social purpose in providing a more effective nation-wide organization of the labor market than would otherwise exist. In order to obtain benefits the unemployed worker must maintain an active registration for work at a local public employment office. These employment offices are welded together in a state-wide and a nation-wide organization under the United States Employment Service. This organization maintains a job clearance system which makes it possible to refer orders for unfilled jobs from one city to another, or from one part of the country to another. The payment of unemployment benefits serves to bring into these offices all workers who have rights 
under the unemployment compensation system. Not only that, but the administration of the system keeps these workers currently registered for as long as they hope to draw benefits. After that, such registration for work has become a habit, and the worker continues to visit the office regularly. Furthermore, the success of the Employment Service in finding jobs convinces the worker that he should keep in touch with his local employment office. ${ }^{23}$

However, a case is sometimes made out against unemployment compensation on the following grounds. Unemployed workers, no matter how genuine their unemployment, are out of work because there are no jobs available for them at their previous wages. They must learn to accept this and make their readjustments accordingly. The speediest reemployment and the quickest return to prosperity would be assured if these workers were forced by economic necessity to readjust their wage and skill demands and take whatever jobs they can find at whatever wages they can get. This is the classical theory of the deflation of the labor market in times of depression.

There is no space here to enter into a discussion of the further economic consequences of such a policy, of the effect upon other wages and the employment of other workers, and upon business itself. Instead, just one aspect of this argument will be examined here. It seems clear that this thesis is based upon the assumption that the economic interests of the community are best served by the speediest possible reemployment of these workers at whatever wages and whatever skills they can find jobs. I believe that the economic interest of the community in the short run may be exactly the opposite-i.e., to give them time to find jobs at their former wages and with their former skills. Among all the reasons which may be advanced for high productivity for the American economy during the last four years of the war, there is one which must not be overlooked, namely, the great opportunity which workers throughout industry have had to choose the work which they like best and can do best. Many workers beginning at the bottom of the ladder a few years ago have risen to the heights since that time. When we consider the large number of misfits who exist in industry in normal times, we must realize that some of these have been that way solely because of lack of opportunity. Of course, there are still misfits in war industries, many thousands of them, but the chances are that we have never had so many workers in this

23. During the war, when more manpower controls have been partially in effect, all types of workers have been brought to the employment office, and the placements of the United States Employment Service have soared to unprecedented levels. In normal pocetime operations, however, many employers operate their own personnel departments, many unions continue to operate a placement system for their own members, and worlicrs sgels jobs on their own account. In prewar days the Employment Service generally filled from 10 to 20 percent of the job openings occurring in the average local community. 
country engaged in work which they like and with opportunities for rising as fast as their capacities will permit them.

What does a depression with forced unemployment do to such a productive machine? All types of workers, both capable and incapable, are thrown out of employment by the convulsions of an economy in depression. True, those laid off are probably the least satisfactory workers; this is certainly true, if the unemployment is moderate. But the deeper and the more widespread the depression, the more complete the shake-down of the labor force.

It is not good economics for the nation to have these workers forced by family needs and other circumstances extraneous to the labor market to take any jobs that are available. Workers with years of experience at a skilled trade may find themselves forced by bitter necessity to take an unskilled job. The result may be tremendous losses in skills and marked increases in the number of misfits in the productive labor force. It can be argued that ultimately the productivity of the nation will be higher if these workers and their families have some carrying power which will enable them to obtain that precious time necessary to enable them to find another opening at their previous level of skill and at something resembling their former wages. The nation's productivity will be appreciably higher if that result is achieved.

The emphasis in this argument is on the "short run." It is clear that if these workers spend six months to a year looking for work in their own trade without success, then some more fundamental readjustment of the worker may be necessary. Trades and skills do disappear; workers who have climbed the economic ladder often have to step down and start up again. The function of unemployment compensation is to give them short-run carrying power so that they may be able to preserve, to the best of their ability, their skills and their earning power. This is to the economic advantage of the nation as well as of the workers and their families. On the other hand, when fundamental occupational readjustments have to be made, then unemployment compensation should be discontinued, or at least put on another basis, and the workers encouraged and assisted to make such readjustments in their working lives.

\section{Conclusion}

Unemployment compensation in the United States has a deeply significant relationship to the American economy. It is financed almost entirely by a payroll tax on employers. The outstanding feature of this tax is that it is variable in place and in time. Experience-rating systems providing for varying rates of contributions on the part of employers exist in 45 states. The outlook for the future is for continued variation in unemployment compensation tax rates throughout the country. 
This does not mean that the payroll tax, as such, is a bad tax for unemployment compensation purposes. It is the nature of this particular payroll tax-its variability, its uncertainty, and its fluctuation from year to year-which is breeding germs of trouble for business in the years after the war when the rates may be increased and when business is more completely on its own than at present. By contrast, the federal old-age and survivors insurance rate has remained uniform for all employers since the date it was first assessed on January 1, 1937, and the rate itself has been changed only once (January 1,1910 ). If changes are made in this rate in the future, it will be by gradual steps, and in accordance with an established schedule known in advance. Therefore, this payroll tax does not have the same economic effect as the unemployment compensation tax.

In another respect the financing of federal old-age and survivors insurance is different-employees contribute at the same rate as employers. Although in four states employees do make some contributions in unemployment compensation, the rates are not equal to employers', nor are there any signs of a spreading of the idea of employee contributions to other states. The hostility of workers generally to experience rating is likely to inhibit the development of employee contributions in unemployment compensation so long as experience rating exists.

There is much to be said in favor of employee contributions in unemployment compensation; much, also, in favor of government contributions, which do not now exist in the social insurances in the United States. ${ }^{24}$ However, in the discussion in December 1914 in the Senate on the subject of the amendment "freezing" the old-age and survivors insurance tax for another year, there is an implication that government contributions to the OASI program may be necessary in the longer future. ${ }^{25}$ In Great Britain, under the system of financing which exists today, the costs of unemployment insurance are shared in three equal parts by employers, workers, and the government. Under the recent Beveridge proposals the government contribution will be even larger, amounting to one-half the costs for the whole of social

24. The Revenue Act of 1913 does authorize a government contribution to the Bureau of OASI if such is required to finance benefits under the system. Such a contribution is not: now and will not be required for some years to come even if employer and employee contribution rates remain as they are. However, eventually a government contribution of an undetermined amount is in prospect if the Congress does not raies the employer and employee contribution rates to a point sufficient to pay the statutory benefits.

25. In recommending legislation for freezing the tax under OASI, Senator Vandenbarg gave support to Mr. Linton's statement that "It is true that a generation hence the costs of old-age pensions will probably exceed the 6-percent payroll tax rcceipts cventually contemplated by the present law, and that a Government subsidy to mal:e up the difference would be needed. . . . Subsidies to the system of a reasonable amount are nothing to become alarmed about." 
security. It must be recognized, of course, that in Great Britain unemployment insurance covers a larger proportion of the workers for much longer periods of time than in the United States; hence, there is a somewhat greater logic in the government contribution. Also, in this country, the government has in the past supported entirely out of government contributions the WPA and other unemployment relief measures. We do not yet know what the pattern of government action will be in the postwar period, but a strong case can be made out for government contributions to unemployment compensation, at least under certain circumstances.

Suggestions have been made occasionally that all payroll taxes should be abolished and all social security and social welfare programs supported out of government contributions derived from general revenue. Something like this is being attempted in New Zealand. There is, however, no record in any country as yet of the successful maintenance of the social security system without the nucleus of a payroll tax as the basis of its financing.

The variable rates introduced in unemployment compensation by experience rating do not now reflect the results of employment stabilization, nor are they likely to do so until a more settled postwar period arises. Furthermore, experience-rating systems are now so variable in themselves that the experience rates in the different states would not represent the same stabilization achievements even if the system were operating under more favorable conditions. Experience rating in practice has confused the issue of the necessary general rate of taxation for the system as a whole. Thinking on these issues would be clearer if they were disentangled.

The operation of the present largely automatic experience-rating systems in the states gives no assurance that variations in rates over a period of time will be conducive to the best interests of the economy in the transition from war to peace. A tax rate which remains constant from year to year is better than one which fluctuates adversely to the business cycle. It is possible that fluctuations in rates could be devised which would conform more closely to the necessities of economic conditions, but so far no such plan of rate making has been worked out.

On the other hand, it would probably be better economics to have the tax rate more stable, and to absorb more of the changes in benefit payments by greater reliance upon accumulative reserves and future borrowing power than has been the practice in unemployment compensation to date.

Benefit payments in unemployment compensation could loom as a large factor in the postwar period even though they will never constitute more than a fraction of the wage loss suffered by the unemployed. The timing of the payments gives them more weight from an economic 
point of view than their absolute size might indicate. The fact that they are paid only to the unemployed is a guarantee that they will be used where they will do the most good. They do not interfere with reemployment of a worker. They are, therefore, the most flexible and the most effective method of meeting short-run unemployment during depression periods. 